Ika Widiastuti, Decision Tree Dengan Algoritma C-45 Untuk Identifikasi Hama dan Penyakit Bunga Krisan (Chrysantheum Morfilium)

\title{
DECISION TREE DENGAN ALGORITMA C-45 UNTUK IDENTIFIKASI HAMA DAN PENYAKIT BUNGA KRISAN (CHRYSANTHEMUM MORIFILIUM)
}

\author{
Oleh: \\ IKA WIDIASTUTI *)
}

\begin{abstract}
Bunga Krisan (Chrysanthemum Morifilium) merupakan jenis tanaman hias yang cukup digemari oleh masyarakat Indonesia dan cukup mendapat perhatian dari pengusaha bunga karena memiliki daya tarik tersendiri selain sebagai penghias, juga sebagai tanaman pengusir nyamuk dan penyerap polutan. Saat ini permintaan bunga krisan cenderung meningkat pada hari-hari besar kagamaan, atau pada hari khusus seperti perayaan ulang tahun, pesta perkawinan dan acara penambutan tamu. Peluang untuk mengembangkan budidaya tanaman bunga krisan, guna memenuhi kebutuhan baik dalam maupun luar negeri masih cukup luas.
\end{abstract}

Permasalahan yang sering muncul pada bududaya bunga krisan diantaranya adalah penurunan produksi bunga Krisan karena kesalahan dalam penanganan panen bunga krisan yang mencapai rata-rata 21 $\%$ dari produk yang dihasilkan. Selain itu, budidaya krisan di Indonesia sangat tergantung iklim dan intensitas matahari sehingga mempengaruhi musim panen dan juga rentan penyakit.

Disamping itu, pengetahuan petani bunga Krisan akan pengendalian hama dan penyakit bunga krisan masih kurang. Sedangkan ahli dibidang pengendalian hama dan penyakit bunga Krisan juga relatif jarang.

Oleh karena itu penelitian ini menerapkan Decision Tree dengan algoritma C4.5 pada pengambilan keputusan untuk mengidentifikasi hama dan penyakit bunga Krisan yang mengakuisisi pengetahuan seorang ahli (pakar) dibidang pengendaliah hama dan penyakit bunga krisan.

Kata kunci : algoritma C45, decision tree, identifikasi

\section{PENDAHULUAN}

Bungakrisan (Chrysanthemum morifilium ) banyak dibudidayakan terutama di daerah pegunungan, khususnya di dekat kota-kota besar. Bunga Krisan saat ini merupakan bunga potong yang sangat popular di Indonesia. Hampir semua penggemar bunga tidak asing lagi dengan bunga krisan, karena selain tahan lama juga memilliki jenis beraneka warna dan bentuknya bermacam-macam pula. Permintaan bunga krisan saat ini berada pada urutan teratas dibandingkan dengan jenis bunga potong lainnya. Setiap tahun lebih dari dua juta tangkai bunga krisan dibutuhkan oleh pasar domestik. Konsumsi bunga krisan diperkirakan bertambah sekitar $11,3 \%$ per tahun, bahkan semakin meningkat (Rukmana,1997).

Untuk mengantisipasi permintaan yang terus meningkat maka produksi bunga krisan harus ditingkatkan. Kebutuhan benih dan bibitnya yang terus meningkat dari tahun ke tahun menuntut penyediaan benih bermutu yang bebas penyakit sistemik dan hama. Sebagian besar tanaman hias yang dibudidayakan sekarang ini, termasuk krisan bibitnya diperbanyak secara vegetatif. Jika tanaman krisan tersebut terinfeksi sejenis penyakit sistemik yang laten, maka patogen tadi akan ditularkan ke bibit berikutnya melalui cara perbanyakan vegetatif. Infeksi tersebut dapat terjadi berulang-ulang yang akhirnya menyebabkan vigor dan daya hasilnya makin menurun yang disebut degenerasi bibit. Hal ini yang menyebabkan para petani krisan mengalami sedikit gagal panen namun tidak terlalu merugi karena hasil bunga yang kurang sempurna.

Penyakit tanaman dan hama merupakan faktor eksternal yang sangat mempengaruhi kualitas dan produktivitas tanaman. Serangan penyakit tanaman dan hama sangat merugikan tanaman, dan tanpa pengendalian yang cepat dan tepat, produksi akan hancur. Salah satu pengendalian penyakit tanaman dan hama adalah, melakukan penyemprotan obat tanaman dan pupuk. Penyakit dan hama yang menyerang tanaman krisan berubah-ubah setiap waktu, sesuai dengan perubahan musim, sehingga pengendaliannya juga mengikuti pola perubahan musim yang terjadi. Akan tetapi dalam implementasinya, banyak para petani yang menggunakan obat tanaman yang sama dan terusmenerus untuk membasmi hama dan penyakit tanaman. Sehingga hama dan penyakit tanaman yang menyerang krisan akan kebal terhadap obat tanaman yang diberikan. 
Petani krisan harus memvariasikan pengobatan dalam membasmi hama dan penyakit tanaman. Salah satunya mengganti obat tanaman yang pernah digunakan dengan yang baru. Misalnya, pada bulan ini dilakukan penanaman krisan, maka obat tanaman yang digunakan harus berbeda dari sebelumnya. Hal ini untuk menghindari hama dan penyakit tanaman kebal terhadap obat tanaman. Sehingga hasil produksi bunga krisan dipastikan sempurna, terbebas dari hama dan penyakit tanaman dan bernilai jual kualitas tinggi. Kendala yang dihadapi petani krisan adalah kurangnya penyuluhan dari pihak berwenang untuk menjelaskan cara pengendalian hama dan penyakit yang tepat dan akurat.

Sebagai alternatif solusi terhadap permasalahan tersebut, pada penelitian ini dikembangkan sistem pendukung keputusan dalam mengidentifikasi hama dan penyakit bunga krisan menggunakan algoritma $\mathrm{C} 4.5$ pada decision tree.

\section{Pohon Keputusan (Decision Tree)}

Decision Tree atau Pohon keputusan adalah model prediksi menggunakan struktur pohon atau struktur berhirarki. Contoh dari pohon keputusan dapat dilihat di Gambar 1. Disini setiap percabangan menyatakan kondisi yang harus dipenuhi dan tiap ujung pohon menyatakan kelas data. Contoh di Gambar 1 adalah identifikasi pembeli komputer,dari pohon keputusan tersebut diketahui bahwa salah satu kelompok yang potensial membeli computer adalah orang yang berusia di bawah 30 tahun dan juga pelajar. Setelah sebuah pohon keputusan dibangun maka dapat digunakan untuk mengklasifikasikan record yang belum ada kelasnya. Dimulai dari node root, menggunakan tes terhadap atribut dari record yang belum ada kelasnya tersebut lalu mengikuti cabang yang sesuai dengan hasil dari tes tersebut, yang akan membawa kepada internal node (node yang memiliki satu cabang masuk dan dua atau lebih cabang yang keluar), dengan cara harus melakukan tes lagi terhadap atribut atau node daun. Record yang kelasnya tidak diketahui kemudian diberikan kelas yang sesuai dengan kelas yang ada pada node daun. Pada pohon keputusan setiap simpul daun menandai label kelas. Decision Tree mengklasifikasikan data yang diberikan menggunakan nilai dari atribut.

\section{a. Entropy}

Untuk menghitung gain ratio, terlebih dahulu harus diketahui nilai entropy-nya. Entropy merupakan suatu parameter untuk mengukur heterogenitas (keberagaman) dari suatu kumpulan sampel data. Jika kumpulan sampel data semakin heterogen, maka nilai entropy-nya semakin besar. Secara matematis, entropy dirumuskan pada persamaan 1 .

$$
\text { Entropy }(S) \equiv \sum_{i}^{c}-p_{i} \log _{2} p_{i}
$$

(1)

Dimana c adalah jumlah nilai yang ada pada atribut target (jumlah kelas klasifikasi). Sedangkan $p_{i}$ menyatakan jumlah sampel untuk kelas $i$.

b. Gain Ratio

Setelah nilai entropy didapatkan dari suatu kumpulan sampel data, maka kita dapat mengukurefektifitas suatu atribut dalam mengklasifikasikan data. Ukuran efektifitas ini disebut gain ratio. Gain Ratio dihitung berdasarkan split information yang dirumuskan pada persamaan 2 .

SplitInformation $(S, A) \equiv \sum_{i=1}^{c}-\frac{\left|S_{i}\right|}{|S|} \log _{2} \frac{\left|S_{i}\right|}{|S|}$

dimana $S$ menyatakan himpunan sampel data dan $S_{i}$ sampai $S_{c}$ menyatakan sub himpunan sampel data yang terbagi berdasarkan jumlah variasi nilai pada atribut $A$. Selanjutnya, gain ratio dirumuskan sesuai dengan persamaan 3 .

$\operatorname{Gain} \operatorname{Ratio}(S, A) \equiv \frac{\operatorname{Entropy}(S)-\sum_{v \in \operatorname{Values}(A)} \frac{\left|S_{v}\right|}{|S|} \operatorname{Entropy}\left(S_{v}\right)}{\text { Splitinformation }(S, A)}$

dimana $V$ menyatakan suatu nilai yang mungkin untuk atribut $A$, Values (A) merupakan himpunan nilai-nilai yang mungkin untuk atribut $A . S_{v}$ merupakan jumlah sampel untuk nilai $v$ dan $S$ merupakan jumlah seluruh sampel data. Entropy $\left(S_{v}\right)$ adalah entropy untuk sampel sampel yang memiliki nilai $v$.

\section{Algoritma C.45}

Algoritma $\mathrm{C} 4.5$ adalah pengembangan dari algoritma ID3. Oleh karena pengembangan tersebut algoritma C4.5 mempunyai prinsip dasar kerja yang sama dengan algoritma ID3. Tiga prinsip kerja algoritma C4.5 pada tahap belajar dari data adalah:

Pertama, Pembuatan Pohon Keputusan. Obyektif dari algoritma penginduksi pohon keputusan adalah mengkonstruksi struktur data pohon (dinamakan pohon keputusan) yang dapat digunakan untuk memprediksi kelas dari sebuah kasus atau record baru yang belum memiliki kelas. C4.5 mengkonstruksi pohon keputusan dengan strategi divide dan conquer. Pada awalnya, hanya dibuat node akar dengan menerapkan algoritma divide dan conquer. Algoritma ini memilih pemecahan kasus-kasus yang terbaik dengan menghitung dan membandingkan gain ratio, kemudian pada node-node yang terbentuk dilevel berikutnya, algoritma divide dan conquer akan 
Ika Widiastuti, Decision Tree Dengan Algoritma C-45 Untuk Identifikasi Hama dan Penyakit Bunga Krisan (Chrysantheum Morfilium)

diterapkan lagi. Demikian seterusnya sampai terbentuk daun daun.

Kedua, Pemangkasan pohon keputusan dan evaluasi (opsional). Karena pohon yang dikonstruksi dapat berukuran besar dan tidak mudah "dibaca", C4.5 dapat menyederhanakan pohon dengan melakukan pemangkasan

berdasarkan nilai tingkat kepercayaan (confidence level). Selain untuk pengurangan ukuran pohon, pemangkasan juga bertujuan untuk mengurangi tingkat kesalahan prediksi pada kasus baru.

Ketiga, Pembuatan Aturan-Aturan dari pohon Keputusan (Opsional). Aturan-aturan dalam bentuk if-then diturunkan dari pohon keputusan dengan melakukan penelusuran dari akar sampai daun. Setiap node dan syarat percabangannya akan diberikan di if, sedangkan nilai pada daun akan menjadi ditulis di then. Setelah semua aturan

dibuat, maka aturan akan disederhanakan (digabung atau diperumum).

\section{Akuisisi Pengetahuan}

Data yang digunakan dalam penelitian diperoleh dari Direktorat Jenderal Hortikultura, dari hasil wawancara dengan seorang yang telah lama berkecimpung dalam penanganan hama dan penyakit bunga krisan dan dari beberapa literatur. Sumber pengetahuan tersebut dijadikan dokumentasi untuk dipelajari, diolah dan diorganisasikan secara terstuktur menjadi basis pengetahuan.

\begin{tabular}{|c|c|c|}
\hline $\begin{array}{l}\text { Kode } \\
\text { OPT }\end{array}$ & Nama OPT & Jenis \\
\hline OPT01 & Ulat Tanah(Agrotis ipsilon Hufin) & Hama \\
\hline OPT02 & Thrips (Thrips tabaci) & Hama \\
\hline OPT03 & $\begin{array}{l}\text { Lalat Putih } \quad \text { (Trialeurodes } \\
\text { vaporiorum) }\end{array}$ & Hama \\
\hline OPT04 & $\begin{array}{l}\text { Penggorok Daun atau Leaf Miners } \\
\text { (Lyorimza sp) }\end{array}$ & Hama \\
\hline OPT05 & Kutu Daun (Aphids) & Hama \\
\hline OPT06 & Rayap (Coptoternus curvignatus) & Hama \\
\hline OPT07 & Karat Daun & Penyakit \\
\hline OPT08 & Busuk Akar & Penyakit \\
\hline OPT09 & Becak Daun Septoria & Penyakit \\
\hline OPT10 & Penyakit Tepung & Penyakit \\
\hline OPT11 & Nematoda & Hama \\
\hline OPT12 & Kapang Kelabu & Penyakit \\
\hline OPT13 & Layu Fusarium & Penyakit \\
\hline OPT14 & Lanas Daun & Penyakit \\
\hline OPT15 & Virus Kerdil Krisan & Penyakit \\
\hline OPT16 & Ulat Grayak & Hama \\
\hline
\end{tabular}

\section{Hasil}

Dari hasil pengolahan data dan uji coba menggunakan Algoritma C4.5 untuk menyusunan pohon keputusan pada basis pengetahuan dihasilkan pohon (tree) seperti yang ditunjukkan pada gambar 5.1. Dari gambar 5.1 dapat diketahui bahwa bunga merupakan root dari tree. Jika Bunga mengalami gejala layu, maka dapat dianggap bahwa bunga krisan tersebut terserang hama. Jika Bunga mengalami gejala perkembangannya terhambat, atau Bunga mengalami busuk berlekatan maka bunga krisan tersebut terserang penyakit yang disebabkan karena cendawan. 


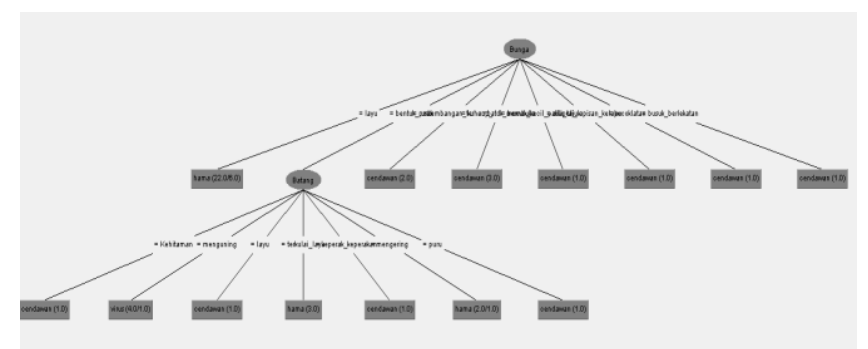

Gambar 5.1 Pohon Keputusan (Decision Tree) untuk deteksi hama dan penyakit krisan

Informasi nilai yang terletak dalam kurung pada setiap akhir node menunjukkan banyaknya data yang dilatih da jumlah data yang salah dikenali. Apabila hanya terdapat satu nilai saja menunjukkan bahwa semua data di akhir node tersebut dapat diklasifikasikan dengan baik. Dari 44 data dengan atribut yang dipilih, 24 data $(54,54$ $\%)$ dapat diklasifikasikan dengan benar, sedangkan 20 data $(45,45 \%)$ salah diklasifikasikan

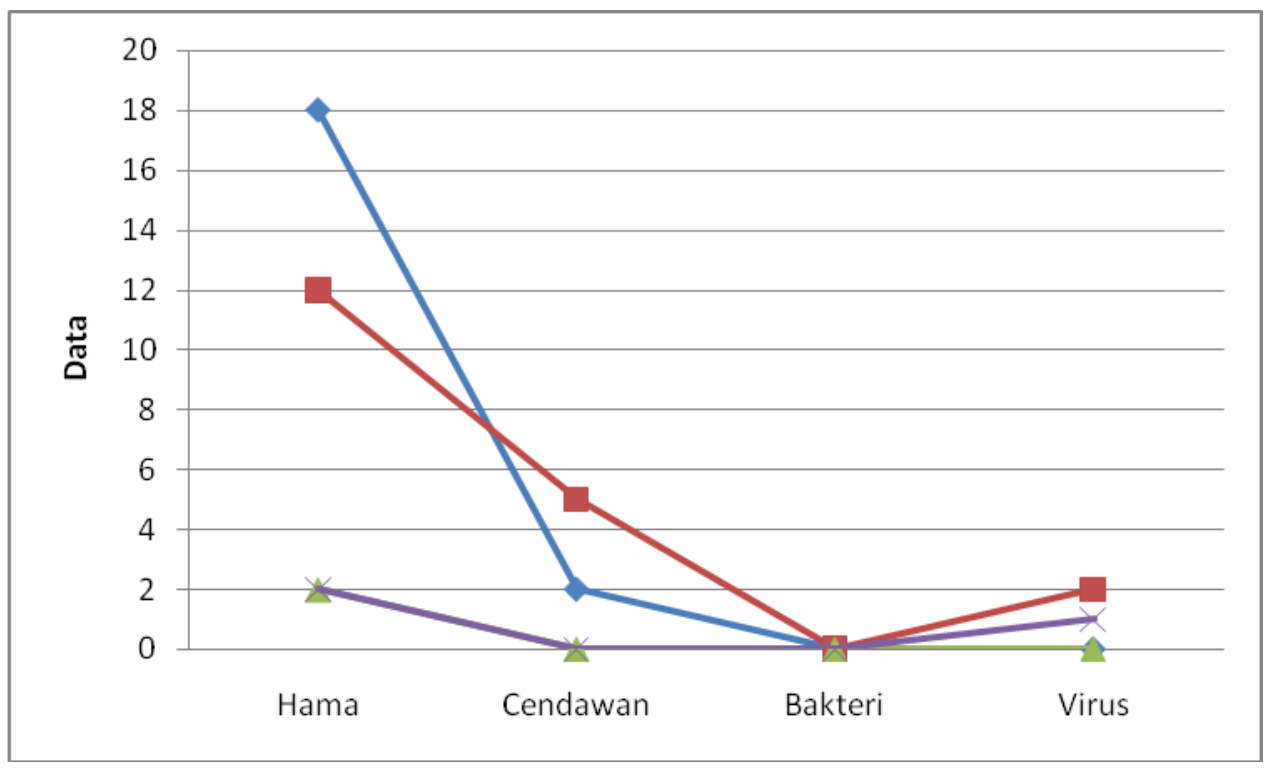

Gambar 4.2 menunjukkan bahwa dari 20 data yang benar terserang hama, 18 data teridentifikasi dengan benar terserang hama dan 2 data teridentifikasi salah yaitu terserang cendawan. Dari 19 data krisan yang benar terserang cendawan, hanya 5 yang teridentifikasi dengan benar terserang cendawan, sedangkan 12 data lainnya salah diidentifikasi yaitu terserang hama. Dari 2 data yang benar terserang bakteri, semua salah diidentifikasi yaitu terserang hama. Dari 3 data yang benar terserang virus, hanya 1 yang benar teridentifikasi terserang viris sedangkan 2 lainnya salah diidentifikasi yaitu terserang hama.

\section{KESIMPULAN}

Pohon Keputusan (Decision Tree) dengan algoritma C4.5 dapat digunakan untuk mendeteksi hama dan penyakit bunga krisan. Dari 44 data sampel, 24 data dapat dikasifikasikan dengan benar sebesar 54,54\%. Untuk memperbaiki kinerja algoritma C.45 diperlukan validasi data oleh seorang pakar. 
Ika Widiastuti, Decision Tree Dengan Algoritma C-45 Untuk Identifikasi Hama dan Penyakit Bunga Krisan (Chrysantheum Morfilium)

\section{DAFTAR PUSTAKA}

Alfiani, Diah. 2002. Sistem Pakar Untuk Identifikasi Kayu. Jakarta: Universitas Gunadarma.

Arhami, Muhammad. 2005. Konsep Dasar Sistem Pakar. Yogyakarta: Andi.

Hartono, J. 1989. Analisis \& Desain. Yogyakarta: Andi.

Nugroho, Bunafit. 2008. Membuat Aplikasi Sistem Pakar dengan PHP dan Editor Dreamwever. Yogyakarta: Gava Media.

Pohan dan Bahri. 1997. Pengantar Perancangan Sistem. Jakarta: Erlangga.

Rukmana, Rahmat dan Asep Eka Mulyana. 1998. Seri Bunga Potong Krisan. Yogyakarta: Kanisius.

Semangun, Haryono. 1994. Penyakit - Penyakit Tanaman Holtikultura di Indonesia. Yogyakarta: Gadjah Mada University Press.

Siswanto. 2010. Algoritma dan Struktur Data Linear dengan JAVA. Jakarta: Graha Ilmu.

Sulistyohati, Aprilia dan Taufiq Hidayat. 2008. Aplikasi Sistem Pakar Diagnosa Penyakit Ginjal Dengan Metode Dempster-shafer. Yogyakarta: Universitas Islam Indonesia.

Supari. 1999. Seri Praktek Ciputri Hijau Tuntunan Membangun Agribisnis. Jakarta: Elex Media Komputindo.

Wahana, Komputer. 2010. Pengembangan Aplikasi Database Berbasis JavaDB dengan NetBeans. Yogyakarta : Andi.

Direktorat Jenderal Hortikultura. 2012. Hama dan Penyakit Krisan 